\title{
犬遊離回腸に括ける尿成分の吸収動態に関する検討
}

\author{
東北大学医学部泌尿器科学教室（主任：折笠精一教授） \\ 岡田 康弘 福崎 篤 折笠 精一
}

\section{ABSORPTION OF THE URINARY CONSTITUENTS FROM CANINE ILEUM}

\author{
Yasuhiro Okada, Atsushi Fukuzaki and Seiichi Orikasa \\ Department of Urology, Tohoku University School of Medicine
}

(Director: Prof. S. Orikasa)

To clarify the mechanism of metabolic changes after using intestinal segments as a urinary tract, absorption of urinary constituents from the ileum was studied in dogs.

An isolated distal ileum ( $30 \mathrm{~cm}$ in length) was anastomosed to the urinary bladder in each dog. Although these animals maintained the normal renal function throughout the experimental period, mild acidosis was noticed one month after anastomosis and it became severe after six months.

Stagnation of a urine-like solution (artificial urine: AU) in the isolated ileum resulted in an absorption of $66 \%$ of the instilled solvent on average during 60 minutes. The average absorption rates of each $\mathrm{AU}$ constituent were as follows: sodium $63 \%$, potassium $80 \%$, chloride $83 \%$, phosphorus $68 \%$, magnesium $34 \%$, urea nitrogen $93 \%$ creatinine $56 \%$, and ammonia $97 \%$. On the contrary, calcium increased in the stagnated fluid by $21 \%$.

In spite of the severe histologic changes in the villi of the ileal mucosa, which became atrophic and flat, no deterioration in the absorptive capacity of the AU constituents was noticed during the six month experimental period.

Furosemide administration suppressed the absorption of urinary constituents, especially water and sodium. On the other hand, the absorption of urea nitrogen and ammonia was scarcely affected.

Perfusion of the isolated ileum with $\mathrm{AU}(0.5 \mathrm{ml} / \mathrm{min})$ for 60 minutes resulted in an absorption of $59 \%$ of the solvent and 50 to $86 \%$ of each constituent. The rate of absorption was reduced after increment of the perfusion rate.

In conclusion, the absorption of urinary constituents occurs rapidly and significantly. The absorptive capacity remains longer regardless the severity of histological changes of the ileal mucosa. These results indicate that an increase in frequency of micturition, an increase in urine volume, and reducing the time of urinary stagnation in the ileum are important to prevent metabolic acidosis after utilizing the ileum as a urinary tract.

Key words: bladder substitution, ureter substitution, intestinal absorption

要旨：腸管を尿路として利用する際に, しばしば問題となる代謝障害の発症要因を明らかにするために, 犬回腸における尿成分の吸収動態を検討した。

遠位の遊離回腸 $(30 \mathrm{~cm})$ を膀朕に吻合した犬は腎機能が正常にもかかわらず 1 カ月後には軽度, 6 カ 月後に著明なアシドーシスを呈した。遊離回腸に停滞させた人工尿は 60 分間に注入量の平均 $66 \%$ ，ナト

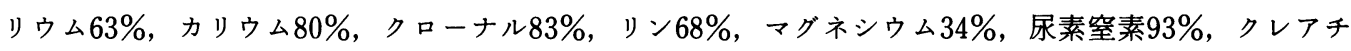
ニン $56 \%$ ，アンモニア $97 \%$ が吸収された。カルシゥムは注入量より回収量が $21 \%$ 増加した。遊離回腸の 絨毛の萎縮や平坦化などの組織学的変化にもかかわらずこの性質は 6 力月間ほぼ不変であった。フロセ ミド投与により水や尿成分の吸収が抑制されたが，尿素窒素とアンモニアの吸収はほとんど抑制されな かった。 また遊離回腸内に人工尿を $0.5 \mathrm{ml} / \mathrm{min} て ゙ 60$ 分間流した結果，注入量の $59 \%$ ，各成分の $50 \sim 86 \%$ が吸収され，流量を増加させると人工尿成分の吸収率は減少した。 
以上より回腸からの尿成分の吸収は高率かつ速やかで, 組織学的変化にもかかわらずその性質は長期 間継続した。 アシドーシスの防止には, 排尿回数あるいは尿量を増加させ，回腸内の尿停滞時間を短く することが有用と考えられた.

キーワード：代用膀脱, 代用尿管, 腸管の吸収

\section{緒 言}

膀胀や尿管の再建に腸管を利用することが広く行わ れている。しかし，腸管を尿路として用いた際に，乙 ばしば代謝異常を伴うことが報告されている。 その発 症要因として腸管からの尿成分の再吸収に加えて, 術 前後の尿路閉塞や感染に伴う腎機能障害が関与してい るものと考兄られているが, その詳細は明らかでない。 本研究は，腸管からの尿成分の吸収動態と，長期間尿 路として利用された腸管の組織学的变化に伴う尿成分 の吸収動態の経時的変化を明らかにする目的で, 犬回 腸を膀胖あるいは尿管として用いた場合を想定した動 物実験で検討を加えた。

\section{対象と方法}

体重 10 ～15kg の雑種犬 20 頭を 5 頭づつ計 3 群に分 け，尿停滞実験と尿流し実験をおこなった。

尿停滞実験群（図 1：A）は初回実験として長さ25 $\mathrm{cm}$ の回腸末端を鉗子にて遮断し(図 $1: \mathrm{A}-1$ ), 表 1 に 示すように調整した人工尿を回腸内に停滞させ人工尿 成分の吸収動態を観察した。次いで遊離した回腸（30 $\mathrm{cm}$ )の口側を閉鎖し膀胱に吻合し（図 $1: \mathrm{A}-2$ )，1 1 力 月， 2 力月拉よび 4 力月後に同様に遊離回腸における 人工尿の吸収動態を観察した（Group A)。さらに Group B として遊離回腸を膀胼に吻合し 6 カ月後の 人工尿の吸収動態を観察した。実験では多孔性のカ テーテルを回腸内に挿入し固定後, カテーテル挿入直 下で回腸 $(25 \mathrm{~cm})$ を鉗子にて遮断し， $38.5^{\circ} \mathrm{C}$ に加温し た人工尿（表 1 ）で回腸内を数回洗浄し，回腸内条件 が安定するまで30４0分間放置した，回腸内液を完全 に排出したのち, あらためて人工尿 $30 \mathrm{ml}$ を回腸内に 60 分間停滞させ， 60 分後に残存した人工尿を完全に回収 するとともに, 大腿静脈, 回腸静脈より採血した（第 一試験). 第一試験終了 30 分後にフロセミド $1.0 \mathrm{mg} / \mathrm{kg}$ を静注し，30分後に人工尿 $30 \mathrm{ml}$ を回腸内に注入し，同 様な実験をおこなった(第二試験)。実験終了後 3 日間 の補液と 5 日間抗生剂投与をした。

尿流し実験群 (Group C)（図 $1 ：$ B）は, Group A, $\mathrm{B}$ と同部位の回腸 $30 \mathrm{~cm}$ を遮断し，口側から人工尿を 滴下し，尾側より流出させ採尿した。第一試験として 人工尿を $0.5 \mathrm{ml} / \mathrm{min}$ で 60 分間滴下，30分の間隔をおい
図 1

（A）尿停滞実験の模式図
(1) 実験開始時

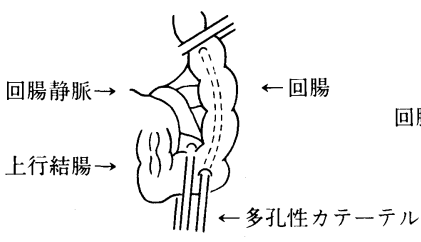

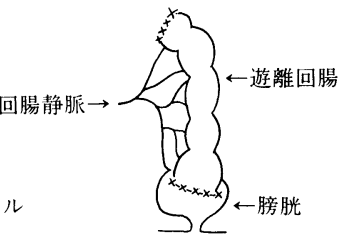

（2）遊離回腸と膀胱の吻合

（B）尿流し実験の模式図
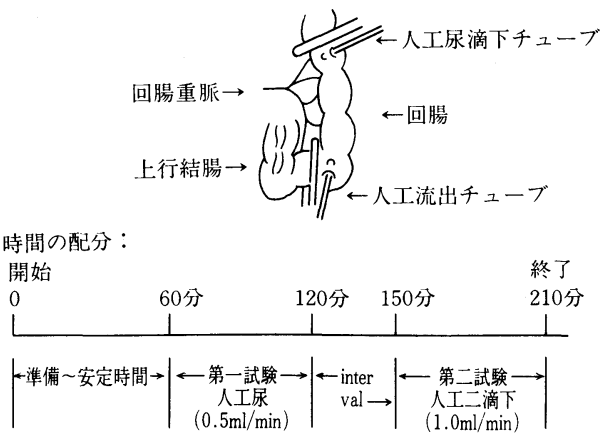

て,さらに第二試験として人工尿を $1.0 \mathrm{ml} / \mathrm{min}$ で 60 分 間滴下した。

両群とも実験前日より12時間の絶食ののち，チオぺ ンタールナトリウム $10 \mathrm{mg} / \mathrm{kg}$ 静注麻醉下に, 腹部正中 切開にて腹腔内に達し, 回腸静脈, 大腿静脈, 大腿動 脈より採血し, 膀胱尿を採取した。実験中は $38^{\circ} \mathrm{C}$ に加 温した生理食塩水 $2 \mathrm{ml} / \mathrm{min}$ で持続静注し, 体温変動を 防止するためヒーティングパットを使用して, 直腸温 を一定に保った。 また血圧測定には圧トランスデュー サー（TP-200T：日本光電）を用い, linearcorder FWR3701 (日本光電) にて実験終了まで持続的に記録 し，血圧に変動のないことを確認した。

血液, 尿の各検体について，ナトリウム $(\mathrm{Na})$ ，カリ ウム $(\mathrm{K})$, クローナル $(\mathrm{Cl})$, カルシウム $(\mathrm{Ca})$, リン 
表 1 人工尿（脱イオン水 $1.0 l$ ）

\begin{tabular}{|c|c|c|c|}
\hline 組 成 & $\mathrm{g} / 1$ & 成分 & 濃度／単位 \\
\hline $\mathrm{Na}_{3} \mathrm{C}_{6} \mathrm{H}_{5} \mathrm{O}_{7} \cdot 2 \mathrm{H}_{2} \mathrm{O}$ & 7.0 & $\mathrm{Na}$ & $71.3 \mathrm{mEq} / 1$ \\
\hline $\mathrm{KCl}$ & 3.3 & $\mathrm{~K}$ & $50.0 \mathrm{mEq} / 1$ \\
\hline $\mathrm{NaCl}$ & 0.7 & $\mathrm{Cl}$ & $71.5 \mathrm{mEq} / 1$ \\
\hline $\mathrm{CaCl}_{2} \cdot 2 \mathrm{H}_{2} \mathrm{O}$ & 0.15 & $\mathrm{Ca}$ & $3.6 \mathrm{mg} / \mathrm{dl}$ \\
\hline $\mathrm{KH}_{2} \mathrm{PO}_{4}$ & 1.5 & $\mathrm{P}$ & $31.0 \mathrm{mg} / \mathrm{dl}$ \\
\hline $\mathrm{MgCl}_{2} \cdot \mathrm{H}_{2} \mathrm{O}$ & 0.3 & $\mathrm{Mg}$ & $3.7 \mathrm{mg} / \mathrm{dl}$ \\
\hline $\mathrm{NH}_{2} \mathrm{CONH}_{2}$ & 8.2 & UN & $408.0 \mathrm{mg} / \mathrm{dl}$ \\
\hline Creatinine & 0.46 & $\mathrm{Cr}$ & $45.0 \mathrm{mg} / \mathrm{dl}$ \\
\hline $\mathrm{NH}_{4} \mathrm{Cl}$ & 0.5 & $\mathrm{NH}_{4}$ & $60.0 \mathrm{mg} / \mathrm{dl}$ \\
\hline \multirow[t]{2}{*}{ D-Mannitol $20 \mathrm{w} / \mathrm{V} \%$} & 50.0 & OSM & $424.0 \mathrm{mOsm} / \mathrm{kgH}_{2} \mathrm{O}$ \\
\hline & & $\mathrm{pH}$ & 6.44 \\
\hline
\end{tabular}

各成分濃度は，人工尿作成後計 10 回測定しその平均值で表 した。

$(\mathrm{P})$ ， マグネシウム $(\mathrm{Mg})$, 尿素窒素( $\mathrm{UN})$ ， クレアチ ニン $(\mathrm{Cr})$, アンモニア $\left(\mathrm{NH}_{4}\right)$ の濃度および尿漫透圧, 尿 $\mathrm{pH}$ を測定し，尿停滞実験群では大腿動脈血の $\mathrm{pH}$, $\mathrm{PCO}_{2}, \mathrm{HCO}_{3}$, B.E. を測定してアシドーシスの有無を 検討した。 をた各実験の一週間前に静脈性腎孟造影お よび膀胱造影を施行し，尿路通過障害の無いこと，膀 胱と回腸の吻合部の交通性が充分に保たれていること を確認した。をた実験終了時膀胱回腸吻合部より約 15 $\mathrm{cm}$ の部位で遊離回腸の一部を切除し, 組織標本を採 取した。組織学的検討は主に絨毛の経時的な形態の変 化の程度を重視し，マイクロメーターを用いて絨毛の 高さと幅について組織計測を打こなった。

\section{結 果}

I . 人工尿停滞実験（Group A, B)

1）経時的人工尿成分の吸収率の变化

人工尿停滞試験（第一試験）における人工尿の吸収 には, 初回から 6 力月間ほとんど変動がみられなかっ た.フロセミド負荷後の（第二試験）には実験開始時 から有意な $(\mathrm{p}<0.05)$ 吸収の抑制を認め，6 月月間そ の傾向に変わりはなかった(図 2 ). 個々の人工尿成分 については Na の第一試験における吸収は 6 力月間ほ ぼ不変であった。フロセミド負荷後（第二試験）には 実験開始から有意 $(\mathrm{p}<0.05)$ な吸収抑制がみられ，6 カ月までその程度はしだいに強まる傾向をみせた，K，

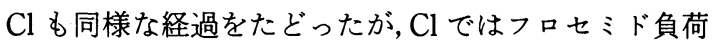
後の吸收抑制が， 2 力月後に比較して 4 力月後には有 意に六進していた（図 3 ）.
図 2 人工尿 $(\mathrm{AU})$ 吸収率の経時的変化. ○：フロセ ミド非投与時, •：フロセミド投与時(mean \pm S.D. : $\mathrm{n}=5$ )

$A U$

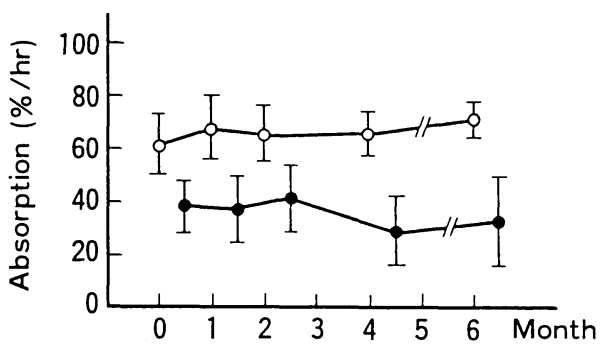

図 3 人工尿中 $\mathrm{Na}, \mathrm{K}, \mathrm{Cl}$ 吸収率の経時的変化. ○： フロセミド非投与時，・：フロセミド投与時 $\left(\right.$ mean \pm S.D. : $\left.\mathrm{n}=5:{ }^{*} \mathrm{p}<0.05\right)$

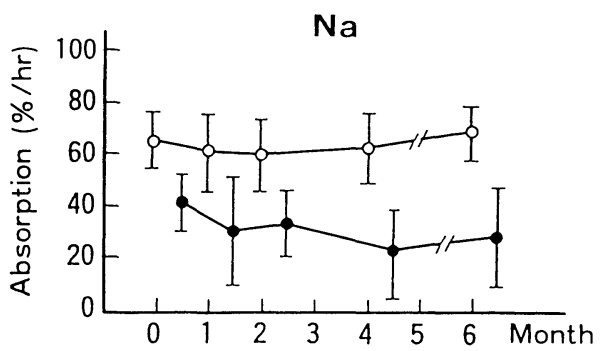

K

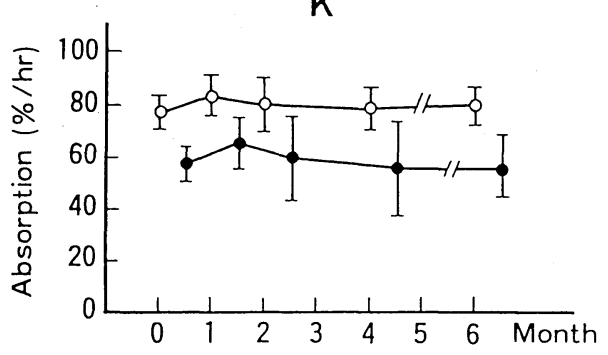

$\mathrm{Cl}$

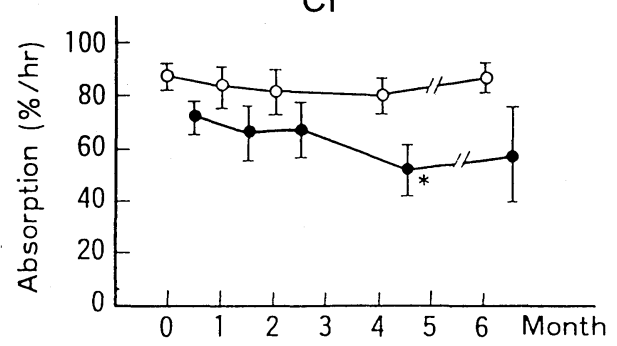

Ca は他の成分と異なり，固体差は大きいものの，実 験開始時より注入量よりも回収量のほうが多く，この 傾向は 6 カ月後まで認められた。フロセミド負荷後に 
図 4 人工尿中 $\mathrm{Ca}, \mathrm{P}, \mathrm{Mg}$ 吸収率の経時的変化. $\mathrm{O}$ ： フロセミド非投与時, ・：フロセミド投与時 (mean \pm S.D. : $\left.\mathrm{n}=5:{ }^{*} \mathrm{p}<0.05\right)$

\section{Ca}

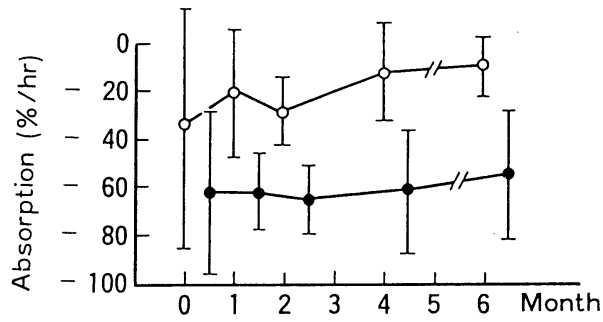

$\mathbf{P}$
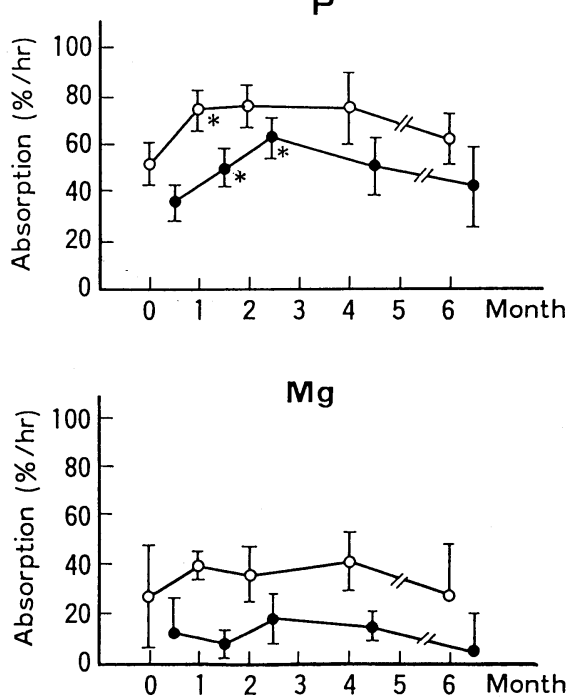

は回収量が,ささらに増加する傾向が認められた. P は 1 カ月後の吸収が初回に比較して有意 $(\mathrm{p}<0.05)$ に増加 し，その後ほぼ不変であった。フロセミド負荷により 吸収は抑制されたが, その作用は 2 力月後まで軽度で, その後六進する傾向があった. $\mathrm{Mg}$ にも同様な傾向が みられたが，有意な変動ではなかった（図 4).UNの 吸収およびフロセミド負荷による吸収抑制作用は 6 カ 月後までほぼ不変であった。 $\mathrm{Cr}$ の吸収もほぼ同様な経 過をたどったが,フロセミド負荷後の吸収抑制作用は, 2 力月後にいったん低下ののち京進する傾向があっ た. $\mathrm{NH}_{4}$ の吸収はきわめて高くこの状態は 6 力月後ま で不変であった。フフセミド負荷による吸収抑制作用 は軽度で, 6 カ月後までほぼ変動は認められなかった (図 5 ).

2）血液生化学検査
図 5 人工尿中 $\mathrm{UN}, \mathrm{Cr}, \mathrm{NH}_{4}$ 吸収率の経時的変化. ○：フロセミド非投与時, ・：フロセミド投与時 (mean \pm S.D. : $\mathrm{n}=5:{ }^{*} \mathrm{p}<0.05$ )

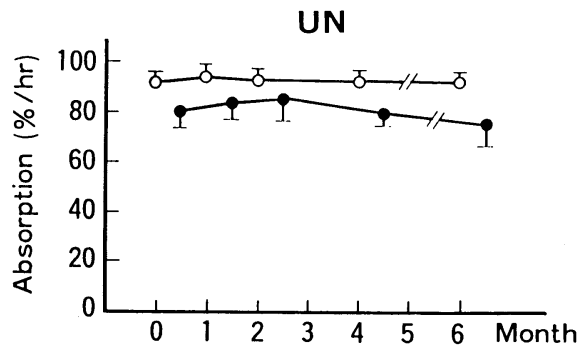

Cr

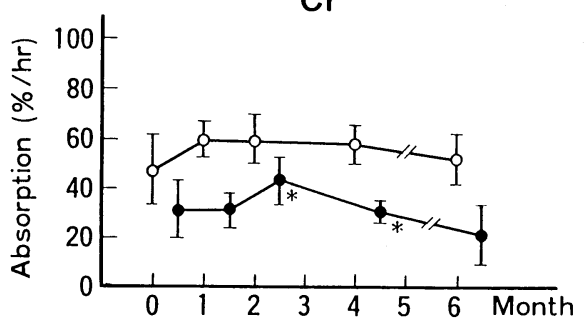

$\mathrm{NH}_{4}$

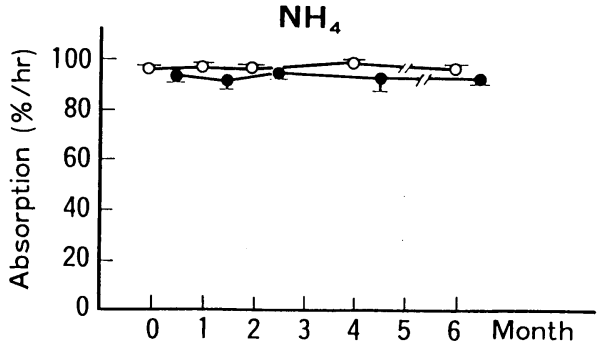

表 2 動脈血ガス分析

\begin{tabular}{|c|c|c|c|c|}
\hline & $\mathrm{pH}$ & $\begin{array}{c}\mathrm{pCO}_{2} \\
(\mathrm{mmHg})\end{array}$ & $\underset{(\mathrm{mEq} / \mathrm{l})}{\mathrm{HCO}_{3}}$ & $\underset{(\mathrm{mEq} / \mathrm{l})}{\mathrm{BE}}$ \\
\hline $\begin{array}{l}\text { 初回 } \\
(0 \text { 月 })\end{array}$ & $\begin{array}{l}7.36 \\
\pm 0.02\end{array}$ & $\begin{array}{l}40.52 \\
\pm 3.65\end{array}$ & $\begin{array}{l}24.1 \\
\pm 1.05\end{array}$ & $\begin{array}{l}-2.24 \\
\quad \pm 1.18\end{array}$ \\
\hline 1 力月 & $\begin{array}{l}7.24 \\
\pm 0.10\end{array}$ & $\begin{array}{l}42.36 \\
\pm 8.15\end{array}$ & $\begin{array}{l}21.5 \\
\pm 4.6\end{array}$ & $\begin{array}{r}-5.98 \\
\quad \pm 5.40\end{array}$ \\
\hline 2 力月 & $\begin{array}{l}* 7.24 \\
\quad \pm 0.06\end{array}$ & $\begin{array}{l}42.8 \\
\pm 4.6\end{array}$ & $\begin{array}{l}* 19.2 \\
\pm 3.4 \\
\end{array}$ & $\begin{array}{l}*-8.06 \\
\quad \pm 4.30\end{array}$ \\
\hline 4 力月 & $\begin{array}{l}7.28 \\
\pm 0.16 \\
\end{array}$ & $\begin{array}{l}35.3 \\
\pm 6.04\end{array}$ & $\begin{array}{l}* 18.7 \\
\quad \pm 2.4\end{array}$ & $\begin{array}{l}*-8.22 \\
\pm 1.39\end{array}$ \\
\hline 6 力月 & $\begin{array}{l}* 7.26 \\
\pm 0.03\end{array}$ & $\begin{array}{c}40.1 \\
\pm 4.6\end{array}$ & $\begin{array}{l}* 19.1 \\
\quad \pm 1.7\end{array}$ & $\begin{aligned} * & -7.74 \\
& \pm 1.48\end{aligned}$ \\
\hline
\end{tabular}

Mean \pm S.D

* $: \mathrm{p}<0.05$ (“0 月”との比較)

大腿動脈血ガス分析の結果は表 2 に示すごとく 1 カ 月後よりアシドーシスの傾向を示し 2 カ月以降はさら 
図 6 人工尿流し実験（Group C) による各成分の吸収率（60分間の回収量/滴下

量). $: 0.5 \mathrm{ml} / \mathrm{min}$ 滴下時,

口: $1.0 \mathrm{ml} / \mathrm{min}$ 滴下時

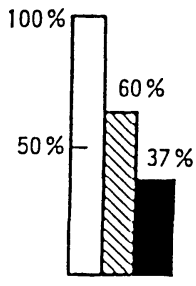

$\mathrm{Na}$

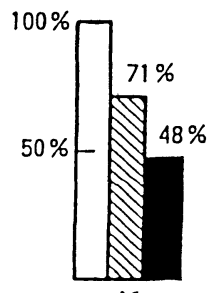

K

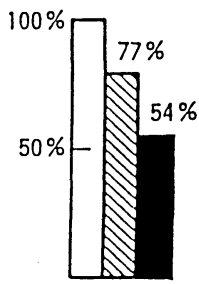

$\mathrm{Cl}$

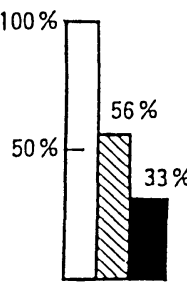

$P$

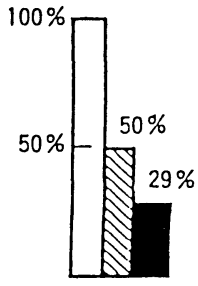

$\mathrm{Mg}$

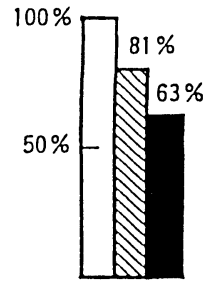

UN

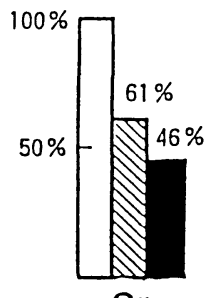

$\mathrm{Cr}$

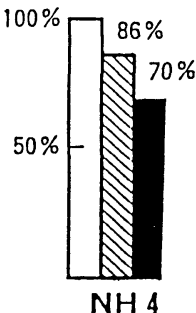

NH 4
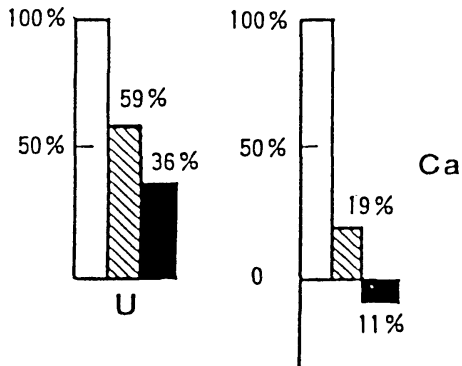

表 3 空置回腸の䄉毛の変化

に著明となった。

また大腿静脈血と比較して回腸静脈血の BUN, Cr, $\mathrm{NH}_{4}$ の濃度は 1 カ月後より高値を示した.

\section{II. 人工尿流し実験（Group C)}

遮断した回腸の口側から人工尿を $0.5 \mathrm{ml} / \mathrm{min}$ で 60 分間滴下したとき，尾側からの流出量は注入量の $41 \%$ であった. 各成分中, 吸収が量も著しかったのは $\mathrm{NH}_{4}$ で, 注入量の $86 \%$ が吸収され，ついで UN が $81 \%, \mathrm{Cl}$ $77 \%, \mathrm{~K} 71 \%$ ， Na と $\mathrm{Cr}$ が60\%程度の順で， $\mathrm{Ca}$ もわ ずかながらであるが流出量が注入量よりも少なかっ た。滴下速度を $1.0 \mathrm{ml} / \mathrm{min}$ としたとき, 流出量は注入 量の $64 \%$ となり, $0.5 \mathrm{ml} / \mathrm{min}$ 滴下時に比較すると流出 率の増加がみられた。 各成分の吸収は, $\mathrm{NH}_{4}$ が注入量 の70\%, UN が63\%， Cl が54\%，K となり Caは流出量が注入量よりも $11 \%$ 多くなった (図 6 ).

III. 組織学的検討

経時的に採取した回腸上皮の䄉毛の高さと幅は正常 の回腸上皮と比較して, 高さが著しく低下し, 幅が広 くなる傾向を示した(表 3 )。この傾向は実験開始 1 力 月から著名で，絨毛上皮下の浮腫や細胞浸潤を伴って いた(図 7 )。２力月後も 1 力月後と同様の所見であっ たが， 4 力月後， 6 力月後にはさらに䋐毛の構築が乱 れ, 平坦化や萎縮, 細胞浸潤の増加が顕著であった。

\begin{tabular}{c|c|c}
\hline$(\mathrm{n}=5)$ & 高さ $(\mu \mathrm{m} \times 100)$ & 幅 $(\mu \mathrm{m} \times 100)$ \\
\hline 正 常犬 & $13.13 \pm 1.19$ & $1.44 \pm 0.27$ \\
\hline 1 カ月犬 & ${ }^{*} 9.76 \pm 0.83$ & $1.51 \pm 0.27$ \\
\hline 2 カ月犬 & ${ }^{*} 8.94 \pm 1.25$ & $1.57 \pm 0.46$ \\
\hline 4 カ月犬 & ${ }^{*} 8.06 \pm 1.23$ & $1.63 \pm 0.23$ \\
\hline 6 カ月犬 & ${ }^{*} 8.81 \pm 0.75$ & $1.57 \pm 0.25$
\end{tabular}

$(\mu \mathrm{m} \times 100:$ Mean \pm S.D $)$

* : $\mathrm{p}<0.05$ (正常犬との比較)

粘膜筋板より䄉毛の先端まで各標本について 5 ケ所以上を 測定してその平均値で表した.

\section{考 察}

腸管を尿路として利用する試みは, 1851年 Simonの 膀胼外反症に対する尿管直腸吻合に始まり，広く泌尿 器科領域で用いられるにいたっている. 1930年頃から 盛んにおこなわれた尿管 S 状腸吻合術後にアシドー シス, 高クロール血症, 低カリウム血症, 高尿素血症 などの代謝障害のおこることが知られ，それは尿と䔬 便とが混合するためと考えられるようになり，それ以 後は尿管 $\mathrm{S}$ 状腸吻合術に代わって回腸あるいは結腸 を用いた導管法や膀胱再建術が主流となっている。し かしながら, 近年, 回腸を利用した尿路形成術後にも 高クロール血性アシドーシスや感染と代謝障害による と考学られる尿路結石の発生が報告されるようにな 
図 7 実験開始 1 力月後の回腸上皮䄉毛の萎縮や短小 化が認められる。（HE 染色, $\times 10)$

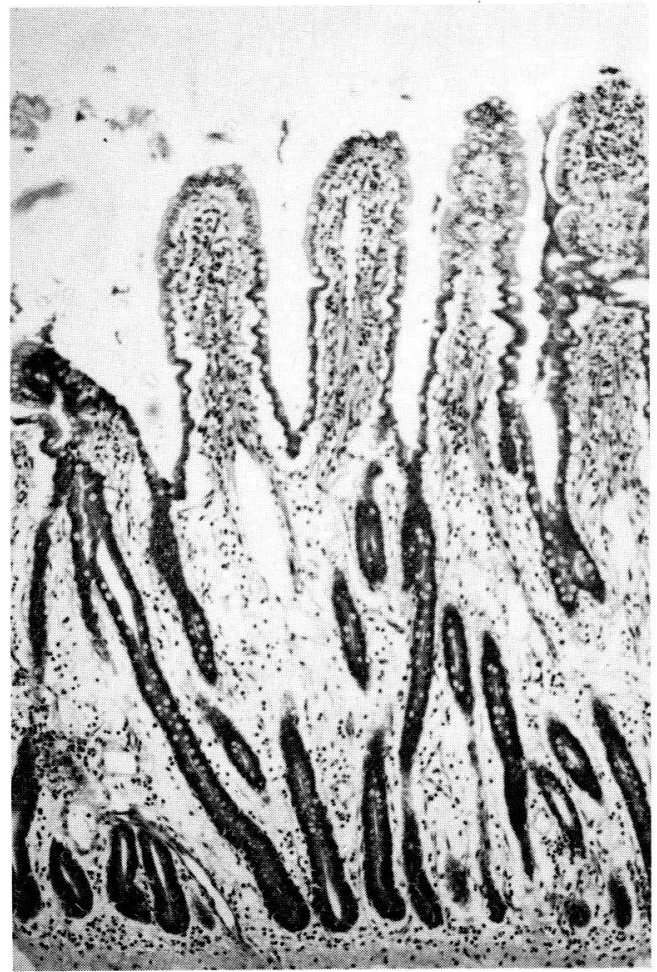

り，このような合併症を防止するら它でも, 代謝障害 発症の機序を詳細に明らかにする必要に迫られてい る、腸管を尿路として用いた症例にアシドーシスや代 謝障害は術後早期に認められた例も含めると10－61\% の合併率が報告されている1) 7). その原因としては，腸 管からの尿成分の吸収に加えて細菌感染, 腎機能障害 の存在，利用した腸管の長さや尿管吻合部の狭窄など が重要とされているが, 臨床的に明らかな感染や腎機 能障害が認められない例にも折笠3) 術後長期間の経過観察において20\%の代謝性アシドー シスを，Castro6) らは回腸を利用した尿路形成術後に 24\%の高氺素窒素血症が認められたと報告し，基本的 には腸管からの吸収あるいは分泌が代謝障害の最大の 要因となっていると考えられる3). 今回の実験の結果 によると，回腸における尿成分の吸収は予想以上に高 率かつ速やかであり，しかしその能力は著しい組織学 的変化にもかかわらず，長期間存続することが明らか となった。 なたフロセミド負荷によりナトリウムを主 とした覀成分の吸収が有意に抑制された。フロセミド の腸管への作用機序については明確にされていないが
腎では主としてヘンレループ上行脚に括ける $\mathrm{Na}, \mathrm{Cl}$

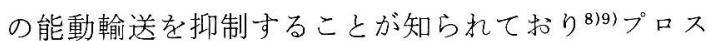
タグランジンの分泌増加作用子有することから ${ }^{10) 111}$ 腸 管,ことに回腸でも同様な機序で $\mathrm{Na} や \mathrm{Cl}$ の吸収を抑 制するものと考学られる。

回腸あるいは結腸を用いた膀胱形成や尿の reservoir を作る術式が最近盛んにおこなわれているが，空 置回腸を膀胱に吻合した本実験でも術後 1 カ月からア シドーシスが認められた。アシドーシスの発症に最も 関与すると考克られる $\mathrm{NH}_{4}$ は60分間の停滞で $96 \%$ 以 上が吸収された． $\mathrm{NH}_{4}$ の輸送動態は，能動的に輸送さ れると考えられる $\mathrm{Na} \mathrm{Cl}$ よりむしろ能動的に輸送 されないUN に近いもので，フロセミドによる吸収抑 制効果も軽度であった.このことは $\mathrm{NH}_{4}$ が従来考学ら れているよらな $\mathrm{NH}_{4} \mathrm{Cl}$ として吸収されているのでは なく, $\mathrm{Cl}$ とは独立して他の機序で輸送されている可能 性を強く示唆するものである.アンモニアの吸収機序 については Resemberg ${ }^{12)}$ は尿管 S 状吻合術後, 腸内に 存在する尿素窒素分解菌により尿素は分解され発生し たアンモニアが $\mathrm{NH}_{4} \mathrm{Cl}$ の形で吸收されると述べてい るが, 新島 ${ }^{13)}$ や村田 ${ }^{14)} ら は$ in vitro でのアンモニア発 生実験を和こない，アンモニアの発生は尿素分解菌に よる尿素の分解だけでは説明できず，各種細菌や腸内 容物の混合の総合的作用によるもので, やはり $\mathrm{NH}_{4}$ $\mathrm{Cl}$ として吸收されると報告している。これに対し Jagenburg ら ${ }^{15)}$ はフンモンは濃度勾配により急速に 腸管より血中へ移行すると述べている.

Caに関しては，注入量よりも回収量が増加した。こ 机は血清と人工尿中カルシウムの濃度差による移動と 考学られたが, 結石発症の一要因として興味が持たれ た. 回腸を利用した尿路変更術や尿路再建術後の合併 症として 4 13\%の尿路結石が報告され2)16) 20), その 原因として腸管の長さ，残尿量，アシドーシス，感染 や水腎症等が検討されている. 残尿量が多くなると腸 管内で $\mathrm{Cl}$ と bicarbonate の交換が容易になり, bicarbonate の喪失が増すと体内の $\mathrm{H}^{+}$インが増加し, 堅 は酸塩基平衡を保つため $\mathrm{H}^{+}$インを排泄する。酸性 度が強くなると骨よりの base とカルシウムの動員が 出現し高カルシウム尿症が生じる21). またアシドーシ スは腎尿細管よりのカルシウムの再吸収を抑制し，尿 中カルシウム排泄が増加し, 結石形成を容易にする17).

今回の動物実験は遊離回腸 $25 \mathrm{~cm}$ を用いて人工尿成 分の吸收の経時的変化を観察し, 同時に遊離回腸 $30 \mathrm{~cm}$ よりの慢性的な犬尿成分の吸収がおよぽす生化学的影 
響について検討したものであるが犬の排尿状態はヒト と異なり膀胼が尿で充満している間が長いと考えられ るため, 本実験結果をそのままヒトに当てはめること はできない，しかし，本実験は腎機能には全く障害を 与えない条件で行われたが，慢性期にはいずれもアシ ドーシスの傾向を呈しており，臨床的にも腸管からの 吸収の程度が強ければ腎機能がさほど障害されていな くてもおこり得ることが示唆された。このようなアシ ドーシスの発症をフロセミド使用等により能動輸送を 抑制することにより予防することは困難と思われ，排 尿回数あるいは尿量を増加させ，腸管での尿の停滞時 間をなるべく短縮させることが最も有用と考えられ た.

\section{結 語}

尿路として利用した腸管における尿成分の吸収動態 を明らかにする目的で，犬遊離回腸を用いて動物実験 を打こない，以下の結果を得た。

1）回腸における尿成分の吸収は高率かつ速やかで あり，長期間尿路として利用された場合も高度な組織 学的变化にもかかわらずその性質は不变であった。

2）フロセミド負荷により,水やナトリウムを主とし た尿成分の吸収低下がみられた。

3）尿素窑素とアンモニアの吸収は最も高率で, フロ セミド負荷による吸収の抑制も軽度であった。

4）腎機能に障害がなくても, 腸管を尿路として利用 すると長期的にはアシドーシスとなり得ることが明ら かとなった。

5）腸管内に尿を通過させるだけでも尿成分の吸収 は括こるが，流量を増加させると吸収率は低下した。

以上から，遊離回腸における尿成分の吸収にはナト リウムを主とした能動輸送の関与が考えられたが，フ ンモニアの輸送は他の機序を介している可能性が大き く, アシドーシスの発症を防止するためには排尿回数 あるいは尿量を増加させ, 腸管での尿の停滞時間をで きるだけ短くするのが最も有用と考えられた。

\section{文献}

1) Remigailo, R.V., Lewis, E.L., Woodard, J,R., Walton, K,N.: Ileal Conduit urinary diversion : Ten-year review. Urology, V11, 343-348, 1976.

2) Schmidt, J,D., Hawtrey, C.E., Flocks, H,R,H. and Culp, D.A.: Complicatins, results and problems of ileal diversions. J. Urol. 109, 210 $-216,1973$.

3）折笠精一：回盲部膀腅形成術. 泌尿器外科, 2(11),
1085-101, 1989.

4) Burnham, J,P. and Farrer, J.: A group experience with uretero-ileal-cutaneous anastomosis for urinary diversion: Results and complications of the isolated ileal conduit (Bricker Procedure) in 96 patients. J. Urol. 83, 622-629, 1960.

5) Kafetsioulis, A. and Swinney, J.: Urinary diversion by ileal conduit: A long-term followup. Brit. J. Urol., 40, 1-11, 1968.

6) Castro J,E. and Ram, M.D. : Electrolyte imbalance following ileal urinary diversion. Brit. J. Urol., 42, 29-32, 1970.

7) Arnalson, O. and Straffon, R.A.: Clinical experience with the ileal conduit in children. J. Urol., 102, 768-771, 1969.

8) Suki, W., Rector, F.C. and Seldin, D.W.: The site of actin of furosemide and other sulfomide diuretics in the dog. J. Clin. Invest., 44, 1458 $-1469,1965$.

9) $\mathrm{SjOstrom,} \mathrm{P.:} \mathrm{Mecchanisms} \mathrm{of} \mathrm{reduced} \mathrm{effects}$ of loop diuretics in healthy volunteers and in patients with renal disease. Scand. J. Urol. Nephrol., Suppl., 111, 1988.

10) Patak, R.W., Mookerjee, B.K., Bentzel, C.J., Hysert, P.E., Babej, $M$ and Lee, J.B.: Antagonism of the furosemide by indomethacin in normal and hypertensive man. Prostaglandins, 10, 649-659, 1975.

11) Weber, P.C and Scherer, B.: Time dependent changes in prostaglandins excretion in response to furosemide in man. Clin. Sci., 56, 77-81, 1979.

12) Resengerg, M.L.: The physiology of hyperchloremic acidosis following ureterosigmoidostomy: A study of urinary reabsorption with radioactive isotopes. Urology, 70, 569-580, 1953.

13）新島端夫：尿管 $\mathrm{S}$ 状腸吻合術後におこるいわゆる 過塩素血性アシドーシスの研究). 第 5 報, 日泌尿 会誌，46，311-331，1955.

14）林田重昭, 桐山蓠夫, 酒徳治三郎：尿管 S 状結腸吻 合術の再検討：電解質を中心とした検討。第 3 報, 泌尿紀要, 19，507-515，1973.

15) Jagenburg, R., Kock, N.G., Norlen, L., \& Trasti, H. : Clinical significance of changes in composition of urine during collection and storage in continent ileum reservoir urinary diversion. Scand. J. Urol. Nephrol., Suppl., 49, 43-48, 1978.

16) Cordonnier, J.J. and Nicolai, C.H.: An evaluation of the use of an isolated segment of ileum as a means of urinary diversion. J. Urol., 83, 834 
$-838,1960$

17) Dretler, S.P.: The pathognesis of urinary tract calculi occurring after ileal conduit diversion: 1. Clinical study. 11. Conduit study. 111. Prevention. J. Urol., 109, 204-209, 1973.

18) Ellis L.R. Udall, D.A. and Hodges C.V.: Furteer clinical experience intestinal segments for urinary diversion. J. Urol., 105, 354-357, 1971.

19) Bitker, R.K.M., Chatelain, C.C. and Lassau J.P. : Indications and early and late results of intestino-cystoplasty: A review of 185 cases. J.
Urol., 103, 53-63, 1970.

20）堀内誠三, 中川完二, 親松常男, 中沢速和, 保坂美 雄, 土屋文雄, 星野嘉伸：結核性萎縮膀胼の回腸拡 大術の成績. 第 1 報. 生存期間, 合併症, 膀胱容量, 電解質なら゙の吸収と一日排泄量の検討。日泌尿会 誌, 73, 1174-1188, 1982.

21) Irving, L. and Chute, A.L.: The participation of the carbonates of bone in the neutralization of ingested acid. J. Cell. Comp. Physiol., 2: 19323-1933, 1957.

（1990年11月22日受理） 